German Journal of Human Resource Research, Vol. 23, Issue 2

Zeitschrift für Personalforschung, 23. Jahrgang, Heft 2, 2009 ZfP 23(2)

German Journal of Human Resource Research

Special issue

Qualitative Methods in Research on Human Resource Management

edited by Hans-Gerd Ridder, Christina Hoon

Hans-Gerd Ridder, Christina Hoon

Introduction to the Special Issue: Qualitative Methods in Research on Human Resource Management

Axel Haunschild, Doris Ruth Eikhof

From HRM to Employment Rules and Lifestyles.

Theory Development through Qualitative Case Study Research into the Creative Industries

Stephanie Kaudela-Baum, Nada Endrissat

Practicing Human Resource Strategy:

Understanding the Relational Dynamics in Strategic HR Work by Means of a Narrative Approach

Julia Hormuth

The Benefits of Discourse Analysis for Human Resource Management

Review article

Wolfgang Mayrhofer

Groping in the Dark? Recent Contributions to Progress in Interpretative Research - a Review

Call for Papers 
Axel Haunschild, Doris Ruth Eikhof*

\section{From HRM to Employment Rules and Lifestyles. Theory Development through Qualitative Case Study Research into the Creative Industries ${ }^{* *}$}

In contrast to result-driven publications in which the academic narrative constructs the process of data analysis and the conceptual framework as purposefully designed and inevitably leading to the findings, this article will take a closer look at the concrete development of interpretative schemes and the openness of this process. We will do so by referring to an extensive empirical study of the German theatrical employment system. Following the course of our research project, the article will explicate and discuss (1) the decision for conducting qualitative rather than quantitative research, (2) the identification and definition of 'what is the case' and how this decision was influenced by ongoing data interpretation and changing and new theoretical inputs, and (3) the question of the generalisability of our findings. The main focus of the article, however, will be to explore the relationship between data and theory. We hope to encourage researchers to creatively use the inherent openness of data interpretation, and we argue that the freedom of qualitative research can only be used in a productive way if methodological decisions and data interpretations are driven by theoretical reasoning.

\section{Von HRM zu Beschäftigungsregeln und Lebensstilen. Theorieentwicklung durch qualitative Fallstudienforschung am Beispiel kreative Industrien}

In ergebnisorientierten Veröffentlichungen werden die Datenanalyse und die Entwicklung eines Analyserahmens in aller Regel so dargelegt, als seien sie gezielt im Hinblick auf die Forschungsfrage gewählt und führten zwangsläufig zu den präsentierten Ergebnissen. Unser Beitrag wird dagegen unter Bezugnahme auf eine intensive Fallstudie zu Beschäftigungsverhältnissen und Personalpraktiken in deutschen Theatern einen genaueren Blick auf die Entwicklung der Dateninterpretation im Forschungsprozess werfen und insbesondere die Offenheiten dieses Prozesses hervorheben. Wir hoffen, Forscher dazu ermutigen zu können, kreativ mit den zwangsläufigen Kontingenzen der qualitative Dateninterpretation in Fallstudien umzugehen, und argumentieren, dass die vorhandenen Freiheiten nur dann konstruktiv genutzt werden können, wenn Methodenentscheidungen und Interpretationsprozesse theoriegetrieben erfolgen.

Key words: case study research, creative industries, employment systems, lifestyles, theatre

* Prof. Dr. Axel Haunschild, Jg. 1964, Professor of Work, Employment and Organisation, University of Trier, FB IV-BWL/APO, D - 54286 Trier. Email: haunschild@uni-trier.de.

Doris Ruth Eikhof, Jg. 1976, Lecturer in Organisation Studies, Stirling Management School, University of Stirling, Stirling, FK9 4LA, Scotland. E-mail: d.r.eikhof@stir.ac.uk.

** The authors would like to thank the editors of this special issue and the two anonymous reviewers for their supportive feedback. Furthermore we would like to thank Barbara Sieben and Jochen Koch for initiating the idea of reflecting about our case study research in the way presented in this paper.

Article received: December 8, 2008

Revised version accepted after double blind review: April 2, 2009.

Zeitschrift für Personalforschung, 23(2), 107-124

ISSN (print) 0179-6437, ISSN (internet) 1862-0000,
DOI 10.1688/1862-0000_ZfP_2009_02_Haunschild (C) Rainer Hampp Verlag, www.Hampp-Verlag.de 


\section{Introduction}

Qualitative research in general and case study research in particular have become an established research approach in management studies. An indicator for the increased use, quality and rigour of qualitative methods as well as the growing methodological self-reflection among qualitative researchers can be seen in the fact that a journal such as the Academy of Management Journal has awarded best paper awards to qualitative, case-based papers (e.g. Ferlie/Fitzgerald/Wood/Hawkins 2005) and has devoted editorials (Suddaby 2006) and discussion forums $(1 / 2007)$ to qualitative methods. One major issue in these discussions has been whether qualitative case study research can (and should) stimulate the advancement and development of concepts and theories (Eisenhardt 1989; Eisenhardt/Graebner 2007; Ridder/Hoon/McCandless forthcoming; Siggelkow 2007; Yin 2003).

This paper refers to an extensive empirical study of the German theatrical employment system in order to show how Human Resource Management (HRM) and organization theories can be advanced by conducting qualitative research methods in empirical HRM research. Our study was carried out between 2000 and 2004. We conducted about 50 semi-structured interviews, collected secondary data from a broad range of sources and were involved in participant observation. Whereas in the beginning our main research question was to identify prevalent HRM practices and the problems of managing a heterogeneous and fairly mobile workforce, the focus of the study as well as the theories and analytical frameworks employed changed during the research process. These developments included a shift from the firm level perspective to an inter-organizational level of analysis, which we conceptualised by using Marsden's theory of employment systems, as well as a shift towards workers' strategies with respect to competitive behaviours and the management of their work-life boundaries. Furthermore, the concept of lifestyle emerged in the process of data analysis and interpretation and was then further developed and backed up by theoretical reflections. The concept of lifestyle, which is common in sociological analysis but has yet hardly been taken up in HRM studies, has proved to be a powerful concept regarding the explanation of industry-wide employment rules and the co-evolution of organizational HR practices and workers' preferences and attitudes.

At the starting point of the empirical research project these outcomes were neither planned nor foreseeable. Rather, results of the study 'emerged' throughout the different phases of the project and were driven by engagement with the literature on new forms of work and organizations, the recent creative industries debate as well as our engagement with social theories (in particular Bourdieu's theory of social practice) in the field of work, employment and organization studies. For this reason, and also because social scientists increasingly show an interest in the creative industries for their (assumed) role as precursors of the world of work in general, our case study research can be an insightful example of how existing theories can be applied to new contexts, how new contexts (creative industries) can reveal new perspectives in other contexts (traditional industries) and how, under certain conditions, qualitative research can stimulate the advancement of existing theories or even the building of new theory. 
Following the course and progression of our research project, the paper will explicate and discuss (1) the decision for conducting qualitative rather than quantitative research, (2) the identification and definition of 'what is the case' and how this decision was influenced by ongoing data interpretation and changing and new theoretical inputs, and (3) the question of the generalisability of our findings, which is linked to the case definition and thus the level of analysis (industry, employment system, organization or theatre actors). The main focus of the paper, however, will be to explain and explore the relationship between data and theory in our study. We will illustrate the relationship between data, theory and theory development by outlining our coding process and data analysis. We will use indicative interview quotes to show how descriptive and categorical codes in the first round of interpretation were developed further under the influence of emerging interpretations and theoretical inspiration, finally leading to new concepts which allowed us to interpret and explain our findings in new and more convincing ways.

In contrast to result-driven publications in which the academic narrative constructs the process of analysis, the literature review and the development of the conceptual framework as purposefully designed and inevitably leading to the findings, we will thus take a closer look at the concrete development of interpretative schemes and the openness and contingency of this process. Such openness and randomness may add fuel to the argumentative fire of those who criticise qualitative research(ers) for an (alleged) lack of rigour and quality standards. We argue, however, that gaining an understanding of social phenomena is an ongoing process that is significantly influenced by the theoretical assumptions we make and therefore should be open to changes to these assumptions as well as for new theoretical inputs. This openness implies scope for interpretation and methodological variations which hence make higher demands on qualitative than quantitative researchers regarding the justification of interpretations, methods and results.

Qualitative researchers face a dilemma. One of the advantages of their research approach is the relative freedom to interpret data and to adapt methods during the research process. On the other hand there is a demand to justify both methodology and results. Most research papers focus on the justification side by using established rhetorics in their methods section. By contrast, this paper focuses more on the 'freedom' side by illustrating the ongoing interpretations and contingency throughout the research process.

In the following section we will make some remarks on case study research in general. Then the context of theatrical work in Germany and the methodology of our case study research project will be outlined. The core section of this article will give a detailed account of the process of data analysis with a particular focus on the development of interpretative and conceptual codes. The discussion and conclusion section seeks to further examine some aspects of this research process such as the contribution to theory development, the validation and generalisation of our findings as well as the problem of defining 'the case'. 


\section{Case study research: Why and how?}

Whereas we all seem to have a certain understanding of what a case study is, clear definitions are hard to find. According to Yin, case study research is "an empirical inquiry that investigates a contemporary phenomenon within its real-life context, especially when the boundaries between phenomenon and context are not clearly evident" (Yin $2003,13)$, and provides "rich, empirical descriptions of particular instances of a phenomenon that are typically based on a variety of data sources" (Eisenhardt/Graebner 2007, 25, referring to Yin; cf. Yin 2003). However, a contemporary phenomenon within its real-life context and rich empirical descriptions based on a variety of data sources can also be studied by or be the result of other qualitative research approaches that do not follow a case-study approach. A more convincing characterisation of case study research is that it investigates a unique and defined social entity as unit of analysis, e.g. an individual, an organization, an industry or an event (Miles/Huberman 1994; Ridder et al. forthcoming). A case study is then defined by what is studied and not by how a phenomenon is studied (see also Stake 2005).

This immediately raises the issue of the representativeness and generalisability of case study results and the question under which conditions such a research approach is justified and possibly superior to other approaches. The latter could be answered by Yin's recommendation that cases should be selected that are unusually revelatory, extreme exemplars or provide opportunities for unusual research access (Siggelkow 2007; Yin 2003). If one of these conditions was met, a case study would generate empirical findings and results which empirical investigations with larger samples or less clearly defined units of analysis are not able to produce. In line with the argument is that an advantage of case studies is seen in the richness and depth of the generated data. However, as mentioned above, the latter is not a unique feature of this empirical approach.

The issue of the representativeness and generalisability is often raised by quantitative researchers who demand statistical significance of empirical findings. What does, from such a perspective, one single case (or a small number of cases in a multiple case study) contribute to extant research? Yin (2003) points out that it is particularly 'why' and 'how' questions that can be answered through case study research. An in-depth study of a defined unit of analysis (the case), in particular when based on a variety of data sources, allows for taking a closer look at perceptions, reflections, justifications and rationales of social practices as well as the context these practices are embedded in and the strategies individual and collective actors develop.

In addition to this particular strength of case study research it is also discussed whether such research strategies can, despite a presumed lack of representativeness and generalisability, go beyond the provision of interesting insights into a single case. Proponents of case study research argue that such contributions could lie in the refinement or extension of existing theories, or even in generating new theories (Ridder et al. forthcoming). For example, a case study could reveal violations of existing theories and thus play a role in challenging existing assumptions and hypotheses or it could provide examples of theoretically developed constructs and thus illustrate the applicability of a theory (Grimshaw 2005; Ridder et al. forthcoming; Siggelkow 2007). Finally, 
the case analysis could inspire theory development itself by letting theory emerge from data (Ridder et al. forthcoming; Siggelkow 2007; Stake 2005; Vaughan 1992; Yin 2003). A more positivist approach is taken by Eisenhardt (1989) who sees cases as (ideally replicable) 'laboratory experiments' with the aim of producing theory that is accurate, interesting, generalisable and testable. Interestingly, such claims seem to go far beyond the requirements usually made of quantitative studies. We agree, however, that case study research should aim at going further than pure description and - if possible - exploration, too. In the subsequent section we will provide an example of a concrete process of theory development through case study research.

\section{Our case study: Background, methods and data}

Towards the end of the $20^{\text {th }}$ century, sociological accounts of work and employment in Germany predicted a development from long-term employment centred on welldefined professions and skills towards a more flexible use of labour based on atypical or non-standard work arrangements (Bosch 2001; Keller/Seifert 1995; Schmid 2000). While such developments had occurred earlier in, for instance, the US and the UK (Cappelli 1995; Polivka/Nardone 1989), employment practices in Germany had been firmly rooted in principles of collective bargaining on industry level, comparatively strict laws regulating employee dismissal and extensive internal labour markets for skilled and professional labour. The overall perspective had been one of mutual longterm commitment, and HRM practices centred on employee development and career planning. Flexibilisation of work and employment thus meant profound changes to the German system.

Against this backdrop, we intended to research the tendencies in work-related and organizational practices and discourses resulting from an increased flexibilisation of work and employment. On the organizational level, we wanted to investigate whether a flexibilisation of employment prompted changes in HRM practices, for instance in recruitment or personnel development, and what the consequences of flexible forms of work were for organizations, for instance for their capacity to attract and retain key human resources. Two other levels of investigation emerged later in the research process (see next section). On the level of industries or employment systems, we were interested in the institutional prerequisites of flexible forms of employment and sought to identify those conditions particularly enabling the spread of new forms of employment. Finally, we were interested in the individual and societal consequences of flexible work, such as their impact on work motivation, career planning and relationship between work and life.

In order to pursue our initial research questions, we decided to conduct an indepth study of an industry in which non-standard or flexible forms of work and organization were already established. This was the case in the creative industries, i.e. those industries in which economic activity is based on the commodification and marketisation of artistic and creative work practices. For centuries, the production of movies and TV, performing and visual arts or music has been organized in projects and with project-based employment. While in some creative industries such as advertising, opera or ballet, projects are closely attached to stable organizations (e.g. Caves 2000), other industries, such as film and TV production, are wholly structured around 
projects as temporary organizations (Jones 1996; Windeler/Sydow 2001). Depending on the extent of the projectification of production, the creative industries generally feature employment relationships that are non-standard with respect to contracts, working hours and workplaces and, consequently, high inter-organizational labour mobility. For the world of work in general, though, it was unlikely that the increase in flexible forms of production would lead to a complete projectification of all employment. To be able to draw general conclusions from our research, we therefore chose to study a creative industry that featured non-standard, flexible forms of work and employment, but was structured around projects attached to relatively stable organizations - the German theatre industry.

The German theatre industry is characterised by a stable set of strong organizations on the one hand and flexible forms of employment on the other. In Germany's fragmented political landscape of the $18^{\text {th }}$ and $19^{\text {th }}$ century, princedoms, electorates and free cities took pride in establishing their own resident theatre companies funded by taxes and donations. This industry structure persisted and today German constitution protects the status of 151 theatres as publicly financed producers of art, who can operate almost independently from product markets. Most of these theatres are medium-sized and employ about 200-400 non-artistic, permanent staff. About 20-50 artistic staff, including the theatre manager, a theatre management group and the 'ensemble' (a relatively stable group of actors, similar to a professional football club's squad), are employed on temporary contracts. In addition, directors, stage and costume designers as well as guest actors work as freelancers with contracts for one play. Production is organized in projects. For each play, theatre managers assemble a project team of ensemble actors, guest actors, directors, stage, costume and light designers and other artistic and non-artistic staff. In so doing, they chose artistic staff from in- and outside the theatre. As careers in theatre are understood as a sequence of projects such transorganizational staffing processes lead to a tense competition especially between actors both within the ensemble and industry-wide.

For our study of work and employment in German theatre, we selected a qualitative approach for two reasons: First, when starting our empirical research hardly any previous studies were available on work, employment and HRM in theatres. Therefore, a deeper understanding of this field had to be gained first. Second, we sought to explore perceptions and HRM practices in theatre, more concretely: why do we observe certain practices and how are they perceived and enacted by the actors and organizations involved. Such questions can hardly be answered by starting with a quantitative analysis since this requires narrowing down and identifying the aspects studied before collecting the data.

Following this reasoning, qualitative empirical data and secondary data were collected in a sequence of studies conducted between 2000 and 2003. The first set of interviews (12 interviews) was carried out in a German repertoire theatre (Staatstheater) financed by public subsidies and situated in a city with approximately 500,000 inhabitants. Interview partners here included the theatre manager (artistic director), a senior administration manager, a director, a project coordinator and several actors linked to the theatre by different contractual arrangements. The second set of interviews ( 5 interviews) was conducted with representatives of inter-firm institutions: the national 
employers' (Deutscher Bühnenverein) and employees' (Genossenschaft Deutscher Bühnen-Angehöriger (GDBA)) associations, the state-run work agency for actors (ZBF) and a state-run theatre school. A third set of interviews (30 interviews) was conducted with theatre actors, dramaturges, directors and a theatre manager in two repertoire theatres situated in one of the biggest cities in Germany. The interviewees comprised ensemble members as well as self-employed theatre artists. All interviews were conducted as in-depth, semi-structured interviews using an interview schedule that allowed for considerable flexibility and minimised disruptions of the natural flow of narratives (cf. Gläser/Laudel 2004; King 1994; Miles/Huberman 1994). Additional information was collected in participant observation which comprised attending premiere celebrations, gatherings after shows, rehearsals and other cultural events (e.g. readings) as well as informal discussions. To validate the subjective information collected (or better: produced) in the interviews, interview material was triangulated with information from secondary data sources such as statistical reports (e.g. by Deutscher Bühnenverein and Genossenschaft Deutscher Bühnen-Angehöriger), media coverage on the German theatre industry and individual artists in newspapers and practitioner journals and information given on theatres' and intermediary organizations' websites.

A clear definition of "the case" was not yet made when we started conducting our interviews. Both, the whole theatrical system (or industry) in Germany as well as the theatre studied in the first set of interviews, were, more implicitly than explicitly, regarded as cases to be studied. As we will show later, the case definition always has to be based on theoretical reflections and can change throughout the process of data interpretation and analysis. Before discussing this further, the next section will illustrate and explain the concrete approach to data analysis (coding) we pursued as well as the iteration of qualitative methods and theory development.

\section{The data analysis: Approaches and ambiguities \\ Coding - Preliminary Remarks}

The richness of qualitative case study data is a particular advantage of this approach but also poses a significant challenge to data analysis. For both the collection of data as well as the analysis of the recorded results of the researcher's observations, decisions have to be made in order to reduce the complexity of social phenomena. Once data are gathered, coding is a process of bringing structure into the data. Coding is necessarily a selective process that requires (preferably, but not necessarily, explicit) theoretical assumptions or theory-based propositions (see also Siggelkow 2007; Yin 2003). It is thus a common misunderstanding that grounding theory in data (Glaser/Strauss 1967; Strauss/Corbin 1990; Suddaby 2006) implies theory-free data collection.

Coding is often described as a process in which data are interpreted and analysed starting with open or descriptive codes, based, for example, on initial assumptions or issues covered in interview guidelines. In a next step, more abstract, interpretative or categorical codes are developed. A final step could lead to conceptual, theoretical or pattern codes (see Miles/Huberman 1994 for a detailed explanation of this process; see also Böhm 2007; Glaser 1978 for a classification of 'code families'). 
In our study, we followed these proposed phases of coding. In this process, we employed some basic principles of Grounded Theory: (1) constant comparison (the critical evaluation of emerging constructs against ongoing observations), (2) theoretical sampling (samples of subsequent phases of data collection were based on interpretations and conceptualisation of previous data), and (3) category saturation as a means of verification. Although using these principles, our approach differed from a pure Grounded Theory approach in so far as rather than just developing a theoretical framework from the data or further developing an existing theoretical framework, we brought in new theoretical approaches during the data collection and interpretation process. The selection of these new theoretical approaches was partly inspired by the data interpretation itself, partly by purposeful searching for additional theories and partly just a matter of 'chance' or 'luck'. In the remainder of this section we will provide examples from our data analysis which illustrate the iterative interplay between data collection, coding and theory development.

\section{Research questions}

Alongside the iteration of data collection, data analysis and theoretical concepts, our research questions developed in mainly three phases. Initially, we intended to study two questions: (1a) How do theatres manage their heterogeneous and flexible workforce? What are the central HRM practices and organizational strategies? (1b) What can we learn from theatre for current trends in work and employment in general? In the second phase we sought to identify and analyse (2a) inter-organizational structures, employment rules and relevant actors in the employment system, and (2b) the individual consequences of flexible forms of work. The third phase focused more on the link between individual practice and their social embeddedness: (3a) How do (theatre) artists experience and reconcile tensions between arts and business (management, market, economy)? (3b) How can we explain the acceptance of "precarious" forms of work in the creative industries? How these questions emerged and developed in the process of data interpretation will be explained further in the remainder of this section. We have to emphasise that it is, according to the focus of this paper, not the aim here to present, explain and discuss our research findings as we have done in other publications (see, for example, Eikhof 2009a, 2009b; Eikhof/Haunschild 2004, 2006, 2007; Haunschild 2003, 2004, 2008; Haunschild/Eikhof 2009).

\section{First phase: Work arrangements and HRM}

As outlined in the previous section, a general shift from standard to non-standard or flexible forms of employment inspired us to study work arrangements and HRM in theatres. Based on concepts like the flexible firm model, i.e. core-periphery structures (Atkinson 1984), boundaryless careers (Arthur/Rousseau 1996) and social capital (Bourdieu 1983; Coleman 1988) we assumed that flexible forms of work and employment required HRM practices that addressed the potential erosion of social capital resulting from more transient relationships, workers' increased mobility between organizations and workforce heterogeneity. Our interview guideline for the first set of interviews therefore covered issues such as the interviewee's work arrangement, the perception of problems of diverse work arrangements, characteristics of artistic theatre work, opinions on what holds theatre together, and how HRM practices (recruitment, 
staffing, development, working time, leadership, compensation, performance appraisal, workforce structure/segmentation, employee relations) were perceived.

The interview guide line was used as a first set of descriptive codes in order to structure the material. When we designed the guideline our knowledge of work and HRM in theatre was rather basic. We then were surprised to realise that no HRM practices in the traditional sense of, for instance, personnel development or performance evaluation and appraisal, could be found in theatre. Consequently, we had to take a more deductive approach. We sought to identify and analyse those practices that, albeit not in the form of traditional HRM practices, nevertheless served as functional equivalents of traditional HRM practices. We discovered that some of these practices, most notably recruitment and performance evaluation, were located not on the organizational level, but on the level of the industry and that HRM as well as individual practices are highly influenced by social networks that span across organizational boundaries.

\section{Second phase: Employment system and project-based production}

In addition, we became familiar with David Marsden's theory of employment systems which seeks to explain the differences between and consistency of institutional frameworks in which HRM practices are embedded (Marsden 1999). Our initial findings were so re-interpreted and more interviews were conducted with representatives of inter-firm institutions (see method section) in order to identify and analyse interorganizational structures, employment rules and relevant actors in the employment system. Whereas the first set of interviews focused on individual perceptions of practices, the second set of interviews treated the interviewed representatives of inter-firm institutions as industry experts and sought to extract their knowledge about industry structures and practices in general. At this time, we also considered other theories and perspectives that conceptualise the inter-organizational level and can thus help to understand the embeddedness of organizational practices. Among these were the Business Systems Approach (Whitley 1999), Societal Systems of Production (Hollingsworth/Boyer 1997), Organizational Fields (DiMaggio 1986; Scott 2001), Societal Analysis (Maurice/Sorge 2000) and Professional or Occupational Communities (Van Maanen/Barley 1984; Tolbert 1996). However, the theory of employment systems uses a contractual perspective as starting point and draws attention to rules of job design and task assignments, labour market structures (including labour market intermediaries), trainings systems and industrial relations. Among the mentioned theories it is the one which to us seemed to be most appropriate to link concrete work and employment practices with inter-organizational structures. We therefore decided to use this theory to identify employment rules and established institutions in our analysis of the first and the second set of interviews.

From this perspective theatres' and theatres artists' practices appeared to be inseparably embedded in the wider structures of theatre industry and the theatrical employment system. Workplace or HR practices could not be understood without taking into account the prevalence of project-based production, flexible forms of employment, comparatively short job tenure, 'boundaryless' careers (Arthur/Rousseau 1996) and a strikingly explicit focus on transorganizational labour markets (Eikhof 2006; 
Marsden 2004), all of which were framed by an ever-present union contract, the homogenous organization of theatre production in projects and an influential education system. The influence of such structures on organizational practices was so pronounced that it made only limited sense to speak of organizational boundaries - if there were any, they were be extremely porous.

\section{Third phase: Arbeitskraftunternehmer and work-life boundaries}

As we widened our analytical perspective to understand theatre as an industry or employment system, two further important aspects emerged. Firstly, the theatre industry was dominated by a transorganizational network of individual relationships through which reputation was earned, employment contracts were gained and projects were staffed. Secondly, tight labour markets and flexible forms of employment resulted in specific individual practices that required further investigation. Consequently, we designed a third phase of empirical research, at the heart of which were interviews with individual theatre artists (theoretical sampling). These interviews explored biographies and career trajectories, work arrangements, several aspects of flexible work life and its social embeddedness (e.g. the typical work day, family status, leisure pursuits, friends/social relations, dealing with mobility, gender issues, personal development), work experience and motivation (e.g. motivation for a career in theatre in general and for daily work in particular, potential de-motivators, the role of reputation/acknowledgement, identification with employer, work pressure, the perception of team work) as well as the perception of leadership in theatre (e.g. division of labour, role of director, typical conflicts and solutions, role of authority, autonomy). In a first step of analysis, the interviews were coded along these descriptive codes. In addition to the interviews, this research phase featured increased involvement with the theatrical employment system via participant observations, informal discussions etc. (see method section). In comparison to the first phase, data collection in this phase focused much more on individuals' perceptions of theatre work as well as individual career and coping strategies.

A central finding from this third research phase was that theatre artists focused strongly on the acquisition of social capital (work-related network ties) and symbolic forms of cultural capital (reputation, artistic achievements), both of which emerged as essential for a successful (boundaryless) career in this employment system. In doing so, theatre artists employed surprisingly open economic logics and engaged in a strategic marketing of their own labour power via personal networks. At the same time, they showed remarkable dedication to work and organized every aspect of life around it. The following quotes are indicative of our interviewees' descriptions of work experiences and practices:

You are not only exposed to external judgement all the time, you also constantly monitor your own work. It's constant crisis and conflict, there is a low barrier to panic and you are always afraid that you will be cast for too little or too small roles - you are always afraid that theatre management and audience will not love you enough. (actor)

[...] you ask yourself: Have I played enough during the past season? Did I have enough leading roles? Did the directors show enough interest in me? Are there signs that the theatre manager wants to keep me? Or worse: that he wants to get rid of me? (actor) 
Parallel to our process of data interpretation we engaged with sociological debates about changing forms of work and employment which stress an increasing degree of market-based work arrangements and blurring boundaries between work and life (Deutschmann 2002; Hildebrandt 2000; Minssen 2000; Moldaschl 2002; Sennett 1998). As part of the constant process of relating findings back to the literature, we discovered that the findings from our third empirical phase supported a more general theoretical concept developed in these debates: the "Arbeitskraftunternehmer" (selfemployed employee, Voß/Pongratz 1998). This ideal type describes individuals in more market-oriented employment systems as consciously managing, developing and marketing their own labour power and as featuring blurring boundaries between work and a life that is organized around demands of work. The application of Voß and Pongratz' concept to our data indicated that theatre artists could, to a large extent, be understood as such Arbeitskraftunternebmer. This finding supported Voß and Pongratz' concept and at the same time confirmed our initial hypotheses that theatre artists today might be studied as exemplars of future workers in general.

However, despite their Arbeitskraftunternehmer-practices, theatre artists still appeared to be genuinely motivated by a belief in theatre art and described it as a vocation rather than a profession:

Being on stage every night, doing what you are best at and being rewarded with applause and, even, money - that is just the most magnificent thing ever. Everything else becomes less important compared to that. (actor)

One reason for breaking up with my wife was that I had to change places so many times. Still I do not regret moving around that much. (actor)

On the one hand, such dedication towards artistic work at least partly explains why theatre artists accepted "precarious" forms of employment and mobility requirements that were anything but beneficial for their personal relationships. On the other hand, they showcase an intrinsic motivation to produce l'art pour l'art that seems to contradict the Arbeitskraftunternehmers' entrepreneurial attitude towards their own labour power. To explore this contradiction in more detail, we applied Bourdieu's above mentioned theory of practice. Bourdieu $(1984 ; 1993)$ understands individual practice as linked to and motivated by abstract paradigms or logics of practice. In the creative industries, the dominant paradigms turned out to be the contradictory ones of business and art, which means that individual practices are driven by two potentially contradictory logics (an economic logic focus on return in investment and an artistic logic focusing on the production of art for art's sake).

\section{Emerging concept: Bohemian lifestyle}

Following this more conceptual explanation we re-visited empirical data from all three research phases to explore how (theatre) artists reconciled the tensions between arts and business (management, market, economy) in practice. In engaging with both the economization of life-characteristic of the Arbeitskraftunternehmer and with theories of lifestyle and milieu (Bourdieu 1984; Schulze 1992; Vester 2005), we discovered that theatre artists did not only feature a particularly blurred boundary between work and life, but that this blurred boundary was part of a wider concept, a lifestyle, which we identified as bohemian. Employing the notion of bohemian lifestyle was also inspired 
by Florida's (2002) influential book on "the rise of the creative class" as well as Brooks' (2000) description of 'bobos' (bourgeois bohemians). Whereas these publications provide interesting ideas regarding the relevance of lifestyles for understanding the preferences, behaviours and cognitive schemes of a growing group of creative workers, the concept of bohemian lifestyle remains theoretically underdeveloped in these works. We therefore took a closer look at more classical texts on bohemians, such as Kreuzer (1968), Murger (1988/1851) and Stein (1981). Based on these texts we concluded that the bohemian lifestyle is centred around ideas such as selfdevelopment, distinction from other parts of society by clothing, public behaviour and gestures, rejection of economic principles, devotion of (work) life to the production of art as a greater good, subordination of private life to work and, finally, the interpretation of work life in artistic categories.

Re-visiting the empirical data against this backdrop revealed a wealth of practices exhibited by theatre artists that fitted this lifestyle. Theatre artists are flexible, mobile, restless, excessively work-dominated, inconsiderate regarding personal relationships and overtly concerned about employability and their artistic reputation. They rate artistic impact over hierarchical position and artistic reputation over high wages, (net-) work in public spaces (e.g. the theatre canteen or at premiere celebrations) and affirm themselves regularly of their unique- and otherness compared to 'the world out there' (actor):

When travelling on the underground and looking around, I' $\mathrm{m}$ glad not to be one of those grey, worn-out blue or white collar workers. (director)

Based on the conduct of life distinctive for $19^{\text {th }}$ century bohemians as found in the literature as well as the case analysis we summarised our findings by identifying five crucial characteristics of bohemian lifestyle: distinction from bourgeois and middle-class values, devotion to 'art for art's sake', communication in public spaces, artistic perception of work (neglect of economic logics) and subordination of private life to work.

As a next step, we again took up the perspective of the theory of employment systems and asked what role the identified lifestyle plays in regulating and shaping inter-organizationally shared work and employment practices. The above mentioned elements of the bohemian lifestyle allow (theatre) artists to perceive themselves as fully dedicated to artistic production processes, to accept the disadvantages of a workdominated life and, most importantly, to disguise economic rationales and market forces and integrate artistic and management activities. The bohemian lifestyle therefore helps to maintain artistic work motivation, which is the key input of theatre as a creative industry. While it can be interpreted as an individual coping strategy in a specific situation of work and employment, it thus also fulfils an important function for organizations and the industry on the whole: It allows them to keep work arrangements temporary and flexible, to offer less extrinsic incentives and to benefit from devotion and creativity and thus makes creative production viable. While some publications have commented on the fact that creative industries workers share a common lifestyle (i.e. that of the creative class; see Florida 2002), neither the concrete practices of this distinctive lifestyle nor its integrative and stabilising function for individuals, organizations and the creative industries on the whole had been analysed before. It is for this reason that, in our view, the notion of bohemian lifestyle and the identifica- 
tion of its key characteristics as well as its function within the employment system can be regarded as a conceptual (or theoretical) contribution to the literature on creative industries, knowledge workers and changing forms of work and organizations. This contribution was not intended when we started to conduct our case study but emerged from the data analysis which, again, was inspired by a growing body of literature on lifestyles and creative workers. In future research, we seek to build further and closer links between work and employment studies, organization studies, the concept of bohemian lifestyle and existing milieu studies and theories.

\section{Concluding discussion: What is the case?}

The above account of the process of data analysis has revealed that the outcome of this process was heavily influenced by an interaction between data interpretation and theoretical analysis. Rather than directly following the aim of developing new theory from the data, we went through different analytical steps at theoretical and empirical level which finally lead to findings beyond a pure case description or the exploration of research hypotheses and questions for subsequent studies. We see our contribution in (1) the application of existing theories and concepts (theory of employment systems; Arbeitskraftunternebmer, milieu and lifestyle research) to new contexts (theatre), (2) the critical discussion of the applicability of these theories to new contexts, (3) the examination of new fields (creative industries, theatre) and as to whether these can reveal new perspectives fruitful for other contexts (traditional industries), and (4) the development of new conceptual ideas (bohemian lifestyle; work-life boundaries) that help to explain practices and social structures in the industry we studied and might be useful for future studies of other related (creative) industries or different industries.

\section{Validation}

The validation and generalisation of case study results (and qualitative research in general) is extensively discussed in the literature (Grimshaw 2005; Maxwell 2002). Traditional criteria for the quality of (quantitative) empirical analyses such as objectivity, reliability and validity are less appropriate for qualitative research and, in particular, the case study approach: The (creative) process of data interpretation contradicts the idea that different researchers gain the same findings and draw the same conclusions. The uniqueness of the case, which is studied within its "real-life context" (Yin 2003, 13), rules out replicability and thus makes the proof of reliability difficult. And, finally, due to small samples validity measures cannot be based on statistical methods of data analysis.

One solution to these limitations could be to nevertheless accept these criteria as equally valid for case study research and to adapt research design according to these requirements, e.g. by increasing the number of cases or by structuring and standardising the data collection and interpretation processes. This approach, however, sacrifices major advantages of case study research in order to achieve alleged methodological rigour. Another solution could be to develop other quality criteria that are more appropriate. Possible such criteria comprise, for example, communicative (rather than 'technical') validation or inter-subjective comprehensibility, method triangulation, validation of the interview situation, authenticity, provision of details of the research 
process and an honest and transparent discussion of the limitations of the chosen approach (see, for example, Miles/Huberman 1994; Steinke 2007)

In our case study, for example, we used multiple sources (documents, participant observations, interviews with a variety of artists, managers and directors as well as representatives of inter-firm institutions) and triangulated these in different steps and phases of the study, multiple interpretations which were discussed among the interviewers, and interaction with respondents by feeding our findings back into the field through presentations of results, a publication in an among practitioners highly regarded special-interest magazine and subsequent discussions with readers. In addition, empirical and theoretical results were presented and discussed via conferences and journal paper submissions from early stages of the research process onwards. However, sufficient explanation of the methodology, thorough analysis, clear presentation of results and attempts to validate findings are basic requirements, not success factors of case study research.

\section{Generalisation}

Findings of case studies do not just comprise the analysis and explanation of observed practices (career strategies, HRM practices, individual coping strategies) and structures (institutional background, career patterns, social networks etc.), but also theoretical implications and the theories or concepts that emerged (Eisenhardt 1989; Ridder et al. forthcoming ; Siggelkow 2007; Stake 2005; Vaughan 1992; Yin 2003). The generalisability of these findings is strongly linked to the definition of the case and how this definition is explained and theoretically justified.

In order to illustrate the problem of finding a convincing case definition, Siggelkow (2007) uses the example of a 'speaking pig' as an extreme case where a case is a persuasive or powerful example in itself: it is 'unusually revelatory', an 'extreme exemplar' and, perhaps, provides opportunities for unusual research access (Siggelkow 2007; Yin 2003). Should we, therefore, search for talking pigs when we seek to conduct a case study? Some doubts are evident here. A case, even a 'speaking pig' does not speak for itself but needs to be embedded in current debates and should add value to existing research: The case of $\mathrm{X}$ should thus also make a case for $\mathrm{Y}$ !

A descriptive report on a speaking pig might thus be interesting but is unlikely to be regarded as good research. Rather, we expect the case study to answer questions such as: how does the pig speak? Why does it speak? Under which conditions does it speak? Can we expect to find more speaking pigs of this kind? Can we explain our observations with existing theories? Do we have to amend or even reject existing theories? How should the pig be studied next? What potential societal impacts could this case have? An interesting case therefore does not necessarily lead to an interesting case study. And an interesting case study can be a study of a case that is not in itself interesting. What then makes a case study interesting and academically fruitful? An interesting case helps, of course. But there are other factors too, such as the topic studied (its novelty or ability to gain public interest), the sampling strategy, the research setting or the novelty, originality or variety of theoretical approach(es) (see also Ridder et al. forthcoming). 
Zeitschrift für Personalforschung, 23(2), 107-124

DOI 10.1688/1862-0000_ZfP_2009_02_Haunschild 121

German Journal of Human Resource Research, Vol. 23, Issue 2

\section{Is theatre an interesting case? It depends!}

As indicated above, we started our study with the idea that one single theatre could be an interesting case of how employers manage a heterogeneous workforce with flexible work arrangements. Based on additional theoretical input (theory of employment systems) as well as data analysis we came to the conclusion that the case should be defined as the theatrical employment system in which theatres are embedded rather than as a single organization. The concept of Bohemian Lifestyle would not have been emerged if we had stuck to one single organization as unit of analysis. Additionally, after having conducted interviews in two more theatres, we observed some differences of leadership structures between the two and then defined these as 'sub-cases' within the theatrical employment system. Although not intended in the beginning, we therefore ended up with the single case study of the theatrical employment system and a multiple case study of three theatres. These re-definitions of 'the case' were driven by empirical and theoretical considerations and emerged during the research process.

\section{Is a case study of theatre generalisable? It depends!}

A case study on theatre might be regarded by some as interesting in itself because it deals with theatre. It is a unique case which shares some similarities with other creative industries but - at first sight - differs considerably from non-creative industries. Furthermore, the particularities of the German theatrical system might delimit the generalisability of our findings (see Haunschild 2003 for a detailed discussion of this aspect). However, if theoretical concepts come into play, we can, for example, argue that work and employment in (German) theatres show characteristics that social scientists claim to becoming more widespread or even dominant overall such as more marketbased and individualised work relationships, blurring boundaries between work and life or project-based forms of organizing (Boltanski/Chiapello 2005; Bosch 2001; Florida 2002; Voß/Pongratz 1998). By developing the concept of Bohemian Entrepreneur we took up the sociological concepts of class, milieu and lifestyle as well as the (few) existing studies of creative workers' lifestyles and further developed these ideas. Combining this concept with an employment system perspective we argue that shared lifestyles fulfil certain functions in an employment system, e.g. aligning workers' preferences and HR practices. What is generalisable here, in our view, is not a specific lifestyle but the insight that shared lifestyles can be an important explanatory variable in some industries - which will have to be identified in further studies.

\section{Resume}

The aim of this article was to describe, explain and discuss the emergence and development of theory through case study research. It was not at all our intention to present our case study(ies) of German theatre as "best practice" or role models. Rather, we referred to our empirical work in order to reflect upon the process of case study data analysis with all its ambiguities and contingencies in a more upfront way than it is usually the case in academic publications.

What can be learnt from our case is that qualitative research projects often imply a considerable degree of openness (and therefore produce more surprising results than quantitative research), which is also reflected in the fact that in a survey of the Acad- 
emy of Management Journal (2006) most of the articles identified as ,interesting research" had been the product of qualitative/case-based methods. This openness, however, is exactly what reduces the credibility of case study research in the view of quantitative researchers who seek to explore statistical and causal relationships between variables on the basis of large data sets. In line with the case study literature we pointed out that case study research certainly has to take into account problems of validation and generalisability, but we also emphasised that means to do so might differ between different methodological approaches. Moreover, where tensions between openness and acceptance of case study research are based on epistemological paradigms (broadly speaking between objectivist and interpretative approaches), exponents of these paradigms are unlikely to agree on standards for good empirical research. These standards are set within scientific communities and, due to the increasing importance of journal rankings for recruitment and career decisions, more and more by journal editors. Today, young researchers are increasingly encouraged to pursue quantitative research in order to publish in highly ranked journals. However, such paradigms change over time and the example of qualitative research published in the Academy of Management Journal as well as the fact that a sizeable proportion of researchers is open to different methodologies and accepts that different research questions and topics require different methodologies show that demarcations between qualitative and quantitative camps are not as clear cut as it seems. We are optimistic that researchers will always choose their research questions, methods, theories and standards not on the basis of journal policies and rankings alone and that therefore case study research will rather proliferate than diminish.

By presenting and discussing the example of our study of the German theatrical employment system, we hope to encourage researchers to creatively use the openness of case study research. However, the freedom of qualitative research, so we argue, is a strength and weakness at the same time and can only be used in a productive way if methodological decisions and data interpretations are driven by theoretical reasoning.

\section{References}

Arthur, M.B./Rousseau, D.M. (1996) (eds): The Boundaryless Career. A New Employment Principle for a New Organizational Era. New York \& Oxford.

Atkinson, J. (1984): Manpower strategies for flexible organizations. In: Personnel Management, August, 28-31.

Böhm, A. (2007): Theoretisches Codieren. Textanalyse in der Grounded Theory. In: Flick, U./von Kardorff, E./Steinke, I. (eds): Qualitative Forschung. Ein Handbuch. Reinbek bei Hamburg, 475-485.

Boltanski, L./Chiapello, E. (2005): The New Spirit of Capitalism. London.

Bosch, G. (2001): Konturen eines neuen Normalarbeitsverhältnisses. In: WSI Mitteilungen, 54, 219-230.

Bourdieu, P. (1983): Ökonomisches Kapital, kulturelles Kapital, soziales Kapital. In: Kreckel, R.. (ed.): Soziale Ungleichheiten. Soziale Welt, Sonderband 2. Göttingen, 183-198.

Bourdieu, P. (1984): Distinction: A social critique of the judgement of taste. London.

Bourdieu, P. (1993): The field of cultural production. Essays on art and literature. New York.

Brooks, D. (2000): Bobos in Paradise. New York.

Cappelli, P. (1995): Rethinking employment. In: British Journal of Industrial Relations, 33, 563-602.

Caves, R.E. (2000): Creative Industries. Contracts between art and commerce. Cambridge/Mass.

Coleman, J.S. (1988): Social capital in the creation of human capital. In: American Journal of Sociology 94 (Supplement), S95-S120.

Deutschmann, Chr. (2002): Postindustrielle Industriesoziologie. München \& Weinheim. 
Eikhof, D.R. (2006): Transorganisationale Arbeit am Theater: Eine empirische Untersuchung vermarktlichter Arbeitsformen. In: Stiftung Körber (ed.): Mythos Markt? Die ökonomische, soziale und rechtliche Gestaltung der Arbeitswelt. Wiesbaden, 139-155.

Eikhof, D.R. (2009a): Does Hamlet have to be naked? Creativity between tradition and innovation in German theatres. In: Jeffcutt, P./Pratt, A. (eds): Creativity and Innovation in the Cultural Economy. London, 241-261.

Eikhof, D.R. (2009b): The logics of art: analysing theatre as a cultural field. In: Townley, B/Beech, N. (eds): The Discipline of Organizing Creativity: Exploring the Paradox. Cambridge, (forthcoming).

Eikhof, D.R./Haunschild, A. (2004): Arbeitskraftunternehmer in der Kulturindustrie. Ein Forschungsbericht über die Arbeitswelt Theater. In: Pongratz, H.J./Voß, G.G. (eds): Typisch Arbeitskraftunternehmer? Befunde der empirischen Arbeitsforschung. Berlin, 93-113.

Eikhof, D.R./Haunschild, A. (2006): Lifestyle meets Market. Bohemian Entrepreneurs in Creative Industries. In: Creativity and Innovation Management, 15, 234-241.

Eikhof, D.R./Haunschild, A. (2007): For Art's Sake - Artistic and Economic Logics in Creative Production. In: Journal of Organizational Behavior, 28, 523-538.

Eisenhardt, K.M. (1989): Building theories from case study research. In: Academy of Management Review, 14, 532-550.

Eisenhardt, K.M./Graebner, M.E. (2007): Theory building from cases: Opportunities and challenges. In: Academy of Management Journal, 50, 25-32.

Ferlie, E./Fitzgerald, L./Wood, M./Hawkins, C. (2005): The (non) spread of innovations: The mediating role of professionals. In: Academy of Management Journal, 48, 117-134.

Florida, R. (2002): The rise of the creative class and how it's transforming work, leisure, community and everyday life. New York.

Glaser, B.G. (1978): Theoretical sensitivity. Mill Valley/CA.

Glaser, B.G./Strauss, A.L. (1967): The Discovery of Grounded Theory: Strategies for Qualitative Research. Chicago.

Gläser, J./Laudel, G. (2004): Experteninterviews und qualitative Inhaltsanalyse. Wiesbaden.

Grimshaw, D. (2005): Using qualitative data to understand employer behaviour in low-wage labour markets. In: Bazen, S./Lucifora, C./Salverda, W. (eds): Job quality and employer behaviour. Basingstoke, 111-131.

Haunschild, A. (2003): Managing Employment Relationships in Flexible Labour Markets: The Case of German Repertory Theatres. In: Human Relations, 56, 899-929.

Haunschild, A. (2004): Employment Rules in German Theatres: An Application and Evaluation of the Theory of Employment Systems. In: British Journal of Industrial Relations, 42, 685-703.

Haunschild, A. (2008): Challenges to the German Theatrical Employment System: How long-established national institutions respond to globalisation forces. In: Smith, C./McSweeney, B./Fitzgerald, R. (eds): Remaking Management Practices: Beyond Global and National Approaches. Cambridge/UK, 251-270.

Haunschild, A./Eikhof, D.R. (2009): Bringing Creativity to Market. Theatre Actors as Self-employed Employees. In: McKinlay, A./Smith, C. (eds): Creative Labour. Working in the Creative Industries. Palgrave, 156-173.

Hildebrandt, E. (ed.): Reflexive Lebensführung. Zu den sozialökologischen Folgen flexibler Arbeit. Berlin, 151-205.

Hollingsworth, J.R./Boyer, R. (eds) (1997): Contemporary Capitalism. The Embeddedness of Institutions. Cambridge.

Jones, C. (1996): Careers in Project Networks: The Case of the Film Industry. In: Arthur, M.B./Rousseau, D.M. (eds): The Boundaryless Career. A New Employment Principle for a New Organizational Era. New York, 58-75.

Keller, B./Seifert, H. (1995): Atypische Beschäftigung. Verbieten oder gestalten? Köln.

King, N. (1994): The qualitative research interview. In: Cassell, C./Symon, G. (eds): Qualitative methods in organizational research. A practical guide. London, 14-36.

Kreuzer, H. (1968): Die Boheme. Analyse und Dokumentation der intellektuellen Subkultur vom 19. Jahrhundert bis zur Gegenwart. Stuttgart. 
Marsden, D. (1999): A theory of Employment Systems. Micro-foundations of Societal Diversity. Oxford.

Marsden, D. (2004): The 'network economy' and models of the employment contract. In: British Journal of Industrial Relations, 42, 659-684.

Maurice, M./Sorge, A. (eds) (2000): Embedding Organizations. Societal Analysis of Actors, Organizations and Socio-Economic Context. Amsterdam \& Philadelphia.

Maxwell, J.A. (2002): Understanding and Validity in Qualitative Research. In: Huberman, A.M./Miles, M.B. (eds): Qualitative Researcher's Companion. London, 37-64.

Miles, M.B./Huberman, A.M. (1994): Qualitative data analysis. 2nd ed. London.

Minssen, H. (ed.): Begrenzte Entgrenzungen. Wandlungen von Organisation und Arbeit. Berlin, 225-247.

Moldaschl, M. (2002a): Ökonomien des Selbst: Subjektivität in der Unternehmergesellschaft. In: Klages, J./Timpf, S. (eds): Facetten der Cyberwelt: Subjektivität, Eliten, Netzwerke, Arbeit, Ökonomie. Hamburg, 29-62.

Murger, H. (1988/1851): Scènes de la vie de bohème. Paris (first published in 1851).

Polivka, A.E./Nardone, T. (1989): On the definition of 'contingent work'. In: Monthly Labor Review, Washington: Bureau of Labor Statistics, December, 9-16.

Ridder, H.G./Hoon, C./McCandless, A. (forthcoming): The Theoretical Contribution of Case Study Research to the Field of Strategy and Management. In: Ketchen, D.J./Bergh, D.D. (eds): Research Methodology in Strategy and Management. Vol. 5. Elsevier.

Schmid, G. (2000): Arbeitsplätze der Zukunft: Von standardisierten zu variablen Arbeitsverhältnissen. In: Kocka, J./Offe, C. (eds): Geschichte und Zukunft der Arbeit. Frankfurt/M. \& New York, 269-292.

Scott, W.R. (2001): Institutions and Organizations. 2nd ed. Thousand Oaks et al.

Siggelkow, N. (2007): Persuasion with case studies. In: Academy of Management Journal, 50, 20-24.

Stake, R.E. (2005): Qualitative case studies. In: Denzin, N.K./Lincoln, Y.S. (eds): The Sage Handbook of Qualitative Research. 3rd ed. Thousand Oaks/CA, 443-466.

Stein, G. (1981): Vorwort. In: Stein, G. (ed.): Bohemien - Tram - Sponti. Boheme und Alternativkultur. Frankfurt, 9-17.

Steinke, I. (2007): Gütekriterien qualitativer Forschung. In: Flick, U./von Kardorff, E./Steinke, I. (eds): Qualitative Forschung. Ein Handbuch. Reinbek bei Hamburg, 319-331.

Strauss, A.L./Corbin, J. (1990): Basics of Qualitative Research: Grounded Theory Procedures and Techniques. Thousand Oaks/CA.

Schulze, G. (1992): Die Erlebnisgesellschaft. Kultursoziologie der Gegenwart. Frankfurt/M. \& New York.

Sennett, R. (1998): Corrosion of character: The personal consequences of work in the new capitalism. New York.

Suddaby, R. (2006): What Grounded Theory is Not (Editorial). In: Academy of Management Journal, 49, 633-642.

Tolbert, P.S. (1996): Occupations, Organizations, and Boundaryless Careers. In: Arthur, M.B./Rousseau, D.M. (eds): The Boundaryless Career. A New Employment Principle for a New Organizational Era. New York, 331-349.

Van Maanen, J./Barley, S.R. (1984): Occupational communities: Culture and control in organizations. In: Staw, B.B. (eds): Research in Organizational Behavior. Greenwich/Ct., 287-365.

Vaughan, D. (1992): Theory elaboration: The heuristics of case analysis. In: Ragin, C.C./Becker, H.S. (eds): What is a Case? Exploring the Foundations of Social Inquiry. Cambridge, 173-202.

Vester, M. (2005): Class and culture in Germany. In: Devine, F./Savage, M./Scott, J./Crompton, R. (eds): Rethinking class. Culture, identities and lifestyles. Houndmills/Basingstoke, 69-94.

Voß, G.G./Pongratz, H.J. (1998): Der Arbeitskraftunternehmer. Eine neue Grundform der Ware Arbeitskraft? In: Kölner Zeitschrift für Soziologie und Sozialpsychologie, 50, 131-158.

Whitley, R. (1999): Divergent Capitalism. The Social Structuring and Change of Business Systems. Oxford.

Windeler, A./Sydow, J. (2001): Project networks and changing industry practices - collaborative content production in the German television industry. In: Organization Studies, 22, 1035-1060.

Yin, R.K. (2003): Case study research. 3rd edition. Thousand Oaks. 
Order Form / all prices in EURO / all prices inclusive VAT*

\begin{tabular}{|l|c|c|c|}
\hline \multicolumn{1}{|c|}{ Order / Subscription } & & $\begin{array}{c}\text { Delivery charge } \\
\text { all countries } \\
\text { except Germany }\end{array}$ & \\
\hline Zeitschrift f. Personalforschung 1-4/2009 & 60,00 & 12,00 & \\
\hline Zeitschrift f. Personalforschung 1-4/2008 & 60,00 & 12,00 & \\
\hline Zeitschrift f. Personalforschung 2/2009 & 19,80 & 3,00 & \\
\hline ZfP, IP access 2009 (2005-2008 free) & 120,00 & & \\
\hline $\begin{array}{l}\text { institutional rate: ZfP, IP access 2009 } \\
\text { (2005-2008 free) + print 2009 }\end{array}$ & 150,00 & 12,00 & \\
\cline { 1 - 3 } & \multicolumn{2}{|r|}{ Total } & \\
\cline { 2 - 4 }
\end{tabular}

Within European Union: Payment after getting the invoice.

Payment per credit card: Please charge my / our credit account
[ ] American Express
[ ] Visa
[ ] Master Card

[]$\ldots \ldots \ldots \ldots \ldots \ldots \ldots$

Credit account no:

Expiry date:

Name (as it appears on credit card):

Date + Signature:

Payment per cheque: Cheques should be made payable to Rainer Hampp Verlag and be drawn on a German bank.

FAX ++49 823330755 oder e-mail: Hampp@RHVerlag.de

\section{Rainer Hampp Verlag}

\section{Marktplatz 5}

D - 86415 Mering, Germany

(delivery address)

${ }^{\text {* }}$ For European companies: please add VAT: 